\title{
Trekking as a metaphor for medicine and medical education
}

P.R. Shankar ${ }^{\text {, V. Malhotra }}{ }^{2}$

${ }^{1}$ Department of Medical Education, KIST Medical College, Imadol, Lalitpur, Nepal, ${ }^{2}$ Department of Physiology, K Variyar Medical College, Salem, India

\begin{abstract}
Nepal is a favored trekking destination. Over the years a number of trekking styles have emerged and the author sees similarities between trekking styles and methods of medical education. Problembased learning strategies make students more involved in their own learning and teachers act as facilitators. Trekkers and medical students mostly concentrate on the immediate trail or different subjects and are able to obtain an integrated and holistic view only occasionally. The nature of the doctor-patient relationship is changing with patients wanting to play a more active role in their treatment. Workers in the trekking industry and doctors slowly rise through the ranks. Often people take up jobs with more responsibilities and challenges which pay better. Technology has invaded both trekking and healthcare and most of the money is made by middlemen. In addition to other areas medicine is focusing on preparing patients for the final exist
\end{abstract}

Key Words: Problem-based learning, doctor-patient relationship, medicine.

The word 'trek' originated from a Dutch word for travel and with the Dutch migration to South Africa came to be an Afrikaans word meaning migration by oxcart. The term has been modified over the years to mean travel by foot for many days. Nepal is one of the hotspots on the global trekking scene due to various factors. The wide range of landscapes ranging from the 'terai' the flat plains bordering India to the frigid heights of Mt. Everest and the friendly open nature of the people could be important reasons.

\section{Treks and trekking styles:}

In this article the author plans to explore how trekking could be a metaphor for medical education and the practice of medicine. Most treks in Nepal start

Correspondences: Dr. P.R. Shankar

E-mail: ravi.dr.shankar@gmail.com at relatively low elevations climb steadily up, cross a pass and then descend on the other side to a river valley. There are a variety of trekking styles which people choose according to their purse and inclinations. In the simplest style one or more trekkers usually set out carrying their own gear and organizing their own logistics. They spend the night at tea houses (lodges) which are common in the popular trekking areas. The trekker/s could walk with one or more porters who will carry the majority of the gear. If there are no tea houses the trekker/s camps out and the porter may cook for you. The last and the most expensive method is to trek with a retinue of porters, kitchen staff, guides and a head Sherpa or sirdar. 


\section{'Styles' of medical education:}

Looking at the medical education scene in South Asia I see similarities with trekking styles. Previously most medical schools used to be supported by the government. Students were selected through a tough entrance exam and came from 'ordinary' families. Fees were low. These students can be likened to the single trekkers who carry their own backpacks. Trekkers carry guidebooks and maps while students use textbooks to guide them through the difficult terrain of medicine. Teachers could be likened to 'guides' guiding the students (neophyte trekkers) over the difficult terrain ensuring they take the proper trail and eventually reach their destination. Recently a number of medical schools have been opened in the private sector in South Asia. These colleges admit self-financing students who have to pay high tuition and other fees. The self-financing students share many similarities with the group of trekkers who trek with a full retinue. Both depend on others to smooth out and cushion their path over the rough terrain. Also as they have invested a large amount of money both expect a smooth and easy journey to their destination. They expect their 'guides' to read and interpret the maps and other material and chalk out the easiest path to their destination.

In the more traditional learning system, the teachers (guides) usually led the way across the terrain of medicine and students followed the path shown by the guide. With the increasing use of problem-based learning strategies the teacher no longer leads the expedition. He/she acts as a facilitator of the process and keeps watch from a respectable distance. The student is trained in leadership and other requisite skills and a group of students chart their own way across the difficult terrain. The guide (teacher) intervenes only in cases of difficulties.

\section{Guiding patients:}

The landscape of medicine has dark alleys and cul de sacs bristling with death, suffering and despair. Patients often get entangled in these fearful landscapes and the doctor guides the patient away from danger and disease to the balmy and sunny valleys of health and happiness. The doctor-patient relationship is steadily changing. Previously patients expected their doctors to lead them out using their knowledge and experience and they used to blindly follow their doctor's orders. Today with increasing levels of literacy and economic well being patients expect to chart their own path out of the dark and dangerous valleys with the doctor providing help and knowledge and supporting the patients' efforts.

\section{Rising up the professional ladder:}

In Nepal many guides start their career in low paying jobs with the trekking industry. They slowly rise up the ladder eventually rising to the post of head Sherpa or trek leader. The same is true of doctors who start off as medical students, then work as interns, house officers, postgraduate trainees and finally become eligible to be consultants or faculty members. Sherpas with trekking groups in Nepal sometimes switch over to mountaineering expeditions. The greater risks and challenges are offset by the higher pay. Doctors specialize and super specialize tackling more challenging and difficult cases for greater financial rewards. Many guides developing close relationships with their clients. Many are sponsored to do their higher education in the west. Others migrate to developed nations taking better paying jobs in either the tourism or other sectors. Many doctors from Nepal migrate to developing countries. 


\section{Inroads of technology:}

Technology has made steady inroads into trekking and mountaineering. Better trails, improved quality of lodges, better maps, global positioning systems, improved food and better shoes and trekking gear are a few examples. Medicine is becoming dominated by technology and big healing teams. The individual family physician is becoming rarer in the west and even in cities of South Asia. Luckily the individual trekker is still commonplace despite big trekking companies and outfitters. Advanced technology does not come cheap. With increasing investments businessmen and corporate houses are becoming common. Doctors work for a fixed salary or a percentage of the profits. Foreign trekkers pay a large amount to agencies in their countries for planning and organizing their treks. The foreign agency often subcontracts the logistics to an agency in Nepal. This agency then hires sirdars, guides and porters. Only a small percentage of the original fee paid goes into the pockets of the guides and porters. Middlemen gain the most in the transactions. The guides and porters are paid well when compared to the low local Nepalese wage standards. The same is true of the doctors who work in hospitals.

Life is a trek with ups and downs, happiness and sorrows. Death is inevitable. What happens after death? Do we continue our trek on a different plane? Medicine along with religion has an important role in preparing people for the final exit which should be as far as possible without pain and suffering. Medicine these days is increasingly focusing on dying with dignity and preparing patients for the unknown frontier. 